\title{
Folate-mediated chemotherapy and diagnostics: an updated review and outlook
}

\author{
Leyuan $\mathrm{Xu}^{1,2}$, Qianming Bai ${ }^{3,4}$, Xin Zhang ${ }^{5}, \mathrm{Hu}$ Yang $^{1,6,7}$ \\ ${ }^{1}$ Department of Chemical and Life Science Engineering, Virginia Commonwealth University, \\ Richmond, Virginia 23284 \\ ${ }^{2}$ Department of Internal Medicine, Yale University, New Haven, Connecticut 06520 \\ ${ }^{3}$ Department of Pathology, Fudan University Shanghai Cancer Center, Shanghai, China 200032 \\ ${ }^{4}$ Department of Oncology, Shanghai Medical College, Fudan University, Shanghai, China \\ 200032 \\ ${ }^{5}$ Department of Pathology, Fudan University Zhongshan Hospital, Shanghai, China 200032 \\ ${ }^{6}$ Department of Pharmaceutics, Virginia Commonwealth University, Richmond, Virginia 23298 \\ ${ }^{7}$ Massey Cancer Center, Virginia Commonwealth University, Richmond, Virginia 23298
}

Correspondence to: Hu Yang (hyang2@vcu.edu)

This work was supported by the National Science Foundation (CAREER award CBET0954957) and National Institutes of Health (R01EY024072). 


\begin{abstract}
Folate receptor (FR) is highly expressed in many types of human cancers compared to normal cells, and it has been actively studied for developing targeted chemotherapy. Tremendous efforts have been made in developing FR-targeted nanomedicines and translating them into clinical applications. This article provides a concise review on the latest development of folate-mediated nanomedicines and nanoprobes for chemotherapy and diagnostics with an emphasis on in vivo applications. The cellular uptake mechanisms, pharmacokinetics (PK), administration routes and major challenges in FR-targeted nanoparticles are discussed.
\end{abstract}

Keywords: Folic acid; folate receptor; targeted delivery; nanomedicine; diagnosis 


\section{Introduction}

Folate, also known as vitamin $\mathrm{B}_{9}$, naturally occurs in food, and folic acid (FA) is a synthetic form of this vitamin. Folate plays an essential role in one-carbon transfer reactions, which are involved in DNA synthesis and replication, cell division, growth, and survival, particularly in rapidly dividing cells. It is also required for biosynthesis of S-adenosylmethione, which is essential for methylation of DNA, RNA, proteins, and phospholipids [1]. In adult tissues, folate or FA is mainly transported by two transporters: reduced folate carrier (RFC) and folate receptors (FRs). RFC, a ubiquitously expressed anion channel, is a low affinity $\left(\mathrm{K}_{\mathrm{m}}=1-10 \mu \mathrm{M}\right)$ but high capacity transporter $[2,3]$. In contrast, FRs, mainly found in kidney, lung, and placenta, are high affinity but low capacity transporters. Three subtypes of FRs have been identified: FR $\alpha$, FR $\beta$, and FR $\gamma$. Among them, FR $\alpha$ is most widely expressed at very low levels in normal tissues, but it is highly expressed in numerous cancers including ovarian, pediatric ependymal brain, mesothelioma, breast, colon, renal, lung tumors, and head and neck carcinomas, in order to meet high folate demand of rapidly dividing cells under low folate conditions [4].

$\mathrm{FR} \alpha$, a membrane-associated form of FR, is normally expressed at the apical (luminal) surface of epithelial cells to keep itself away from and out of direct contact with folate in the circulation [5, 6]. However, carcinoma cells allow FR $\alpha$ accessible to folate in the circulation by alteration of the transmembrane region, transcriptional level and translational level of FR $\alpha$ [7-9]. Elevated FR $\alpha$ expression could increase folate uptake to stimulate cellular DNA repair during the 
early stages of carcinogenesis. The continued expression of FR $\alpha$ could then support the transition of cellular environment that favors uncontrolled rapid growth of tumor cells [10]. The FR $\alpha$-positive tumor (nonmucinous epithelial ovarian carcinoma) reveals that the level of FR $\alpha$ protein expression is closely associated with tumor progression [11]. Because of high tumor-specificity, the exploitation of FR-targeted nanomedicines and nanoprobes rapidly advances cancer chemotherapy and diagnostics. As a potential targeting moiety, FA holds several advantages including low molecular weight and immunogenicity, relatively high stability, and ease of synthesis, compared with most antibodies [12].

Tremendous efforts have been made in developing FR-targeted nanomedicines and translating them into clinical applications. A few FR-targeted chemotherapies have entered clinical trials for cancer treatment. EC0489, a FR-targeted drug conjugate consisting a vinca alkaloid microtubule destabilizing agent linked to an FA molecule, and EC0225, a FR-targeted two drugs conjugate containing two potent cytotoxic agents of vinca alkaloid and mitomycin $\mathrm{C}$ linked to a single FA molecule, are under development by Endocyte Inc [13]. BMS753493, an antimitotic agent containing an epothilone moiety linked to a single FA molecule, is under development by Endocyte Inc. and Bristol Myers Squibb [14]. Vintafolide, a small molecular drug conjugate consisting a potent chemotherapeutic drug of vinblastine linked to an FA molecule, is under development by Endocyte Inc. and Merck \& Co [15]. Mirvetuximab soravtansine (IMGN853), an antimitotic agent (maytansinoid DM4) conjugated to an 
FR $\alpha$-targeting antibody (M9346A), is under development by ImmunoGen Inc. A vaccine adjuvant, FR $\alpha$ peptide vaccine mixed with granulocyte macrophage colony-stimulating factor (GM-CSF), is currently under development by TapImmune Inc. In addition to the ongoing clinical trials, numerous FR-targeted chemotherapies have been developed in the laboratories worldwide. These chemotherapies can be divided by different categories including FA-drug conjugates, FR-targeted nanoparticles, FR-targeted immunotherapies, and FR-targeted imaging and diagnosis. Early findings of folate-related chemo- or immune-therapies have been reviewed and discussed in the twentieth century [9, 16-20]. This article provides a concise review on latest advances in FR-targeted nanomedicines with an emphasis on in vivo findings.

\section{Structural basis of folic acid and folate receptors}

FA is composed of three sub-components, i.e., pterin, para-amino-benzoic acid, and glutamic acid (Figure 1). A recently molecular simulation and docking study revealed the binding sites of FA and FR $\alpha$ [4]. In this study, FA was docked into an extended groove of FR $\alpha$ in the direction roughly perpendicular to the plane formed by helices $\alpha 1, \alpha 2$ and $\alpha 3$. Both hydrogen bonds and hydrophobic interactions occurred around the pteridine ring of FA. The ligand-binding affinity study showed that $-\mathrm{NH}_{2}{ }^{\mathrm{a}}$ of FA bound to D81A of FR $\alpha$. Mutation of D81 of FR $\alpha$ greatly increased the dissociation constant $\left(K_{d}\right)$ value by more than one order of magnitude, the largest increase observed in the study, suggesting the interaction of the aspartate carboxyl oxygens with the pterin $\mathrm{N} 1$ and N2 nitrogens of FA is very strong and contributes to the highest binding 
affinity between FA and FR $\alpha$. In contrast, $-\mathrm{OH}^{\mathrm{b}}$ of FA bound to R103A, R106A and S174A of $\mathrm{FR} \alpha$; $-\mathrm{COOH}^{\mathrm{c}}$ of FA bound to W140A of FR $\alpha$; and $-\mathrm{COOH}^{\mathrm{d}}$ of FA bound to W102A and K136A of FR $\alpha$. Mutations of K136 and R106 have little effect, and mutations of W102, R103, W140, and S174 have moderate effects on folic acid binding [4]. This study illustrates the key binding site of FA to bind to FRa, which provides a structural requirement of the pterin group, especially $-\mathrm{NH}_{2}{ }^{\mathrm{a}}$ function group, for anchoring folate in the binding pocket of the receptor. Given that, the glutamate group of $\mathrm{FA}$, especially $-\mathrm{COOH}^{\mathrm{c}, \mathrm{d}}$, can be used for conjugation with linkages/spacers, drug, contrast reagents or nanoparticles, without significantly compromising the interactions between receptor and ligand.

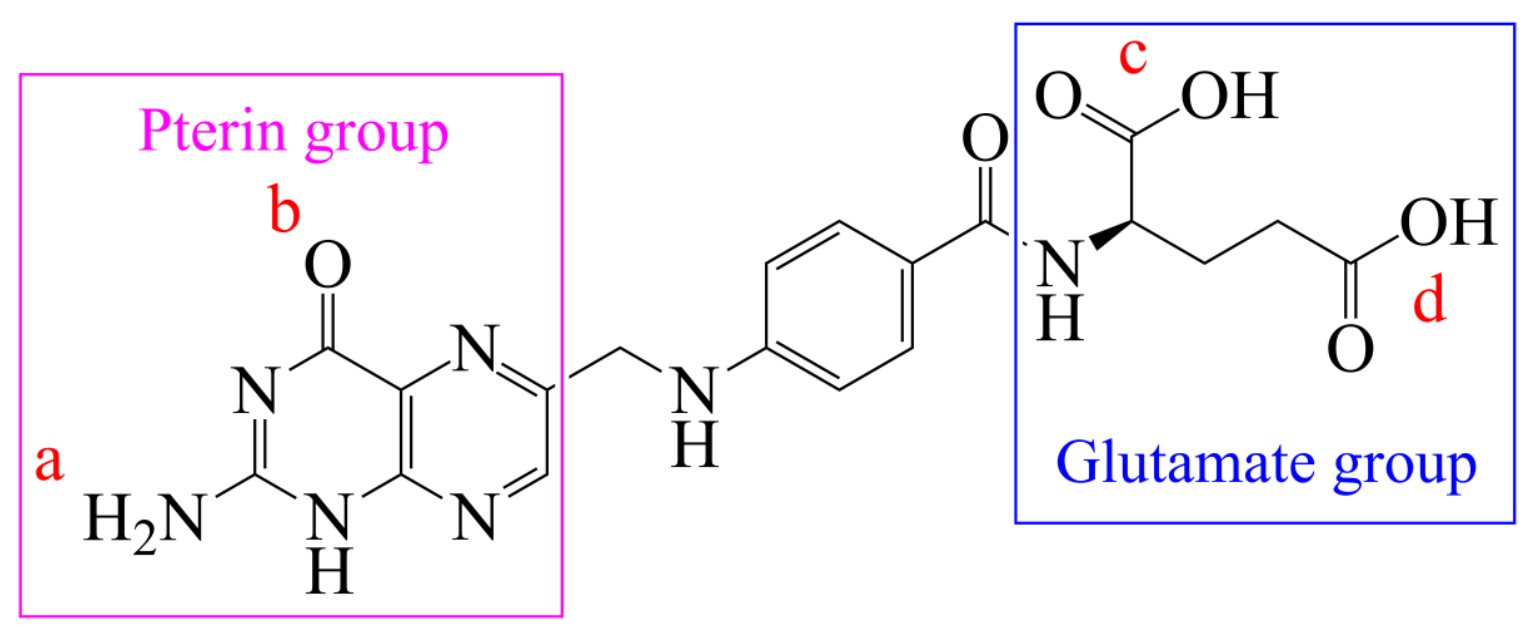

Figure 1. Structure of folic acid

\section{FA-decorated nanomedicines}

Most FA cannot dissolve in water because of its low solubility in water $(0.0016 \mathrm{mg} / \mathrm{mL}$ at $\left.25^{\circ} \mathrm{C}\right)$. Hence, FA is commonly chemically conjugated onto water soluble polymers or 
integrated onto the nanoparticles to prolong the circulation time and guide drug or nanoparticles to the FR highly expressed tumors [12]. Polyethylene glycol (PEG) modification is generally known to increase the solubility of the drug and prolong the half-life of drug in the body, which may passively increase drug accumulation at tumor due to the enhanced permeation and retention (EPR) effect. Additional FA modification may increase retention of the nanoparticle in the tumor mass and facilitate uptake of the nanoparticle by FR-mediated endocytosis, which enables the drug to arrive the FR-highly expressing tumor cells more efficiently and precisely [21]. FA-decorated nanoparticles can be generally synthesized as shown in Figure 2 with minor modification depending on the unique properties of various nanoparticles. A variety of FR-targeted nanomedicines have been developed based on polymer-drug conjugates, liposomes, polymeric micelles, dendrimers, and other nanoparticles such as nanotubes, nanosheets, etc. Most studies suggest that FA decoration allows nanoparticles to enhance drug and gene delivery efficiency to the tumor site, and the major recent in vivo findings were summarized in Table $\mathbf{1 .}$ 


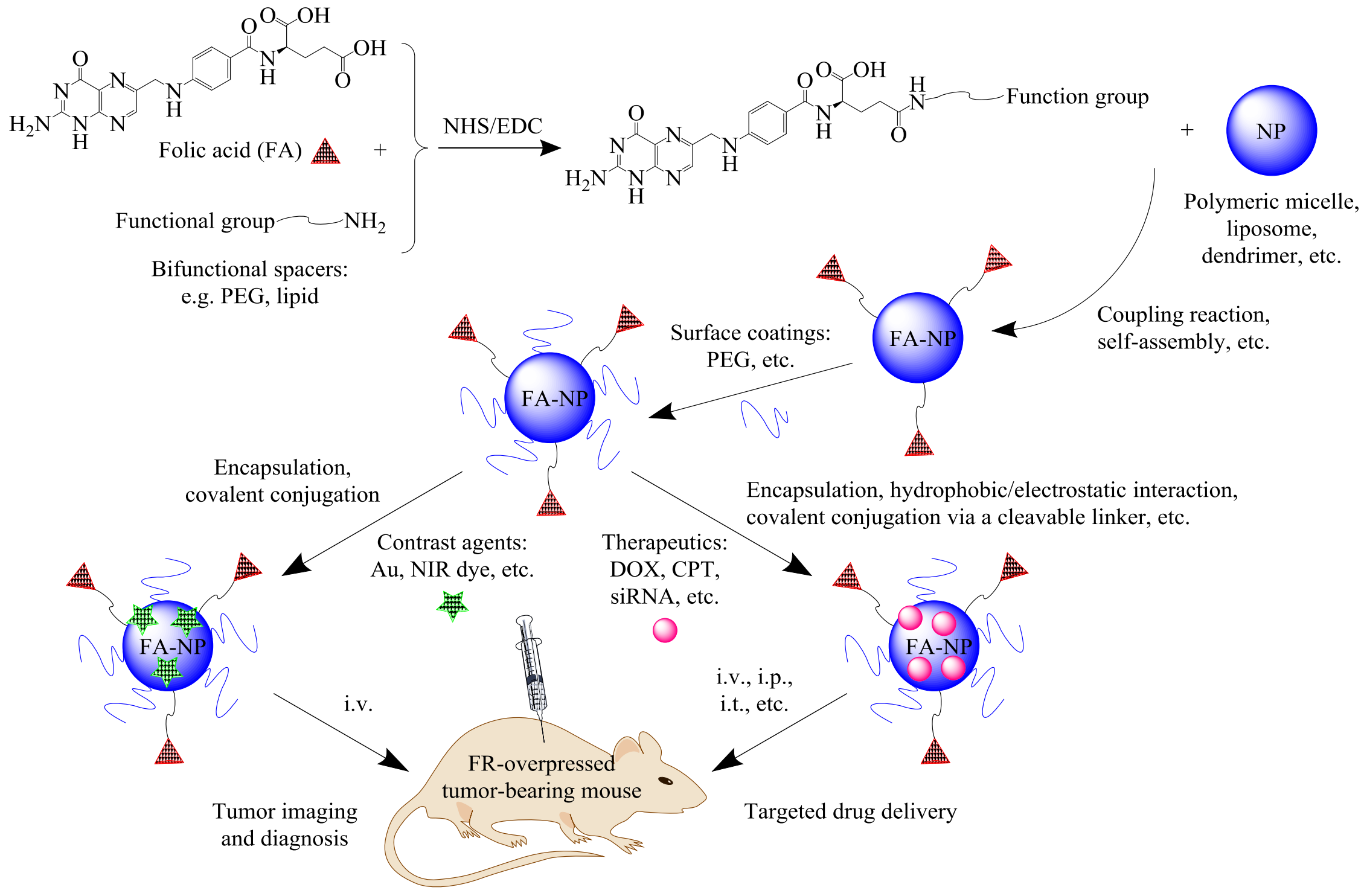


Figure 2. Synthetic scheme of FA-mediated nanoparticle (FA-NP) 
Table 1. Major recent pre-clinical findings of FR-targeted nanomedicines

\begin{tabular}{|c|c|c|c|c|c|}
\hline Nanocarrier & Drug & Model & Route & Major findings & Ref. \\
\hline FR-targeted (FRT) liposome & Carboplatin & $\begin{array}{l}\text { IGROV-1 ovarian } \\
\text { tumor-bearing SCID } \\
\text { BC-17 mice }\end{array}$ & i.p. & $\begin{array}{l}\text { A superior survival rate ( } 5 \text { out of } 6 \text { of mice) } \\
\text { was observed in the mice treated with FRT } \\
\text { carboplatin liposome twice a week for } 3 \\
\text { weeks, and no metastasis was observed in } \\
\text { these mice. In contrast, no survivor was } \\
\text { observed in the mice treated with saline, free } \\
\text { carboplatin or non-FR-targeted carboplatin } \\
\text { liposome, and the cancer cells metastasized } \\
\text { to the lung and liver tissues in these mice. }\end{array}$ & {$[22]$} \\
\hline $\begin{array}{l}\text { FA and TAT peptide conjugated, } \\
\text { octadecyl-quaternized, lysine-modified } \\
\text { chitosan-cholesterol polymeric liposomes } \\
\text { (FA-TATp-PLs) }\end{array}$ & $\begin{array}{l}\text { Paclitaxel } \\
\text { (PTX) }\end{array}$ & $\begin{array}{l}\text { KB nasopharyngeal } \\
\text { tumor-bearing SCID } \\
\text { mice }\end{array}$ & i.v. & $\begin{array}{l}\text { The tumor growth rate of the mice treated } \\
\text { with PTX-loaded FA-TATp-PLs or free } \\
\text { Taxol was reduced by } 71 \% \text { and } 49 \% \text {, } \\
\text { respectively, compared with the one of } \\
\text { PBS-treated mice. } \\
\text { The drug delivery system, FA-TATp-PLs, } \\
\text { had no effect on tumor growth. }\end{array}$ & {$[23]$} \\
\hline $\begin{array}{l}\text { FA-coupled PEGylated nano-paclitaxel liposome } \\
\text { (FA-NP) }\end{array}$ & $\begin{array}{l}\text { Paclitaxel } \\
\text { (PTX) }\end{array}$ & $\begin{array}{l}\text { SKOV3/TAX ovarian } \\
\text { tumor-bearing nude } \\
\text { mice }\end{array}$ & $\begin{array}{l}\text { i.p. } \\
\text { i.v. }\end{array}$ & $\begin{array}{l}\text { i.p. administration of FA-NP but not free } \\
\text { PTX or non-targeted NP significantly } \\
\text { prolonged the survival and reduced tumor } \\
\text { nodule number. } \\
\text { - i.v. administration of FA-NP failed to } \\
\text { achieve these antitumor effects at the same } \\
\text { dose of i.p. administration. }\end{array}$ & [24] \\
\hline $\begin{array}{l}\text { FR-targeted docetaxel-lipid-based-nanosuspensions } \\
\text { (tLNS) }\end{array}$ & $\begin{array}{l}\text { Docetaxel } \\
\text { (DTX) }\end{array}$ & $\begin{array}{l}\text { B16 tumor-bearing } \\
\text { Kunming mice }\end{array}$ & i.v. & $\begin{array}{l}\text { An obvious tumor regression was observed } \\
\text { in the mice treated with tLNS, non-targeted } \\
\text { docetaxel-lipid-based-nanosuspensions } \\
\text { (pLNS), and Duopafei. } \\
\text { - The tumor inhibition rate in the tLNS mice } \\
\text { was higher than that in pLNS and Duopafei } \\
\text { groups. }\end{array}$ & {$[21]$} \\
\hline
\end{tabular}




\begin{tabular}{|c|c|c|c|c|c|}
\hline & & & & $\begin{array}{l}\text { Both tLNS and pLNS induced less toxicity } \\
\text { to the mice than Duopafei via i.v. } \\
\text { administration. } \\
\text { The overall targeting efficiencies of pLNS } \\
\text { and tLNS were } 1.09 \text { and } 1.23 \text { times better } \\
\text { than that of Duopafei, respectively. }\end{array}$ & \\
\hline $\begin{array}{l}\text { FA-conjugated and Rhodamine ( } \mathrm{RHO} \text { )-labeled } \\
\text { PAMAM dendrimer generation } 4(\mathrm{G} 4-\mathrm{RHO}-\mathrm{FA}) \\
\text { emulsified with oleic acid-coated } \mathrm{Fe}_{3} \mathrm{O}_{4} \mathrm{NPs} \\
\left(\mathrm{OA}^{-} \mathrm{Fe}_{3} \mathrm{O}_{4}\right) \text { in the lipid solution to form Mag-pH-DS } \\
\text { dendrosomes }\end{array}$ & DiR dye & $\begin{array}{l}\text { HeLa tumor-bearing } \\
\text { BALB/c nude mice }\end{array}$ & i.v. & $\begin{array}{l}\text { Both non-magnetic pH-DS and Mag-pH-DS } \\
\text { enhanced targeting efficiency compared } \\
\text { with G4-RHO-FA. } \\
\text { Mag-pH-DS treated animals combined with } \\
\text { an external magnetic field had a shorter peak } \\
\text { time with a nearly twice the peak intensity } \\
\text { compared with that without magnetic field. } \\
\text { Mag-pH-DS exhibited superior tumor } \\
\text { accumulation compared with G4-RHO-FA } \\
\text { and pH-DS. } \\
\text { Dendrosomes had higher peak intensity and } \\
\text { a longer residence time than G4-RHO-FA. } \\
\text { The major elimination routes of both } \\
\text { non-pH sensitive DS, pH-DS and } \\
\text { Mag-pH-DS were liver and spleen; whereas } \\
\text { G4-RHO-FA was primarily eliminated by } \\
\text { the kidney. }\end{array}$ & [25] \\
\hline $\begin{array}{l}\text { A heparin-folate-paclitaxel (HFT) backbone with an } \\
\text { additional paclitaxel (T) loaded in its hydrophobic } \\
\text { core (HFT-T) }\end{array}$ & $\begin{array}{l}\text { Paclitaxel } \\
\text { (PTX) }\end{array}$ & $\begin{array}{l}\text { KB-3-1 and KB-8-5 } \\
\text { (PTX-resistant) } \\
\text { tumor-bearing nude } \\
\text { mice }\end{array}$ & i.v. & $\begin{array}{l}\text { HFT-T enhanced the specific delivery of } \\
\text { PTX into tumor tissues, prolonged retention } \\
\text { of PTX within tumor tissues, and markedly } \\
\text { retarded tumor growth. } \\
\text { - The enhanced antitumor effects were } \\
\text { associated with a higher degree of } \\
\text { microtubule stabilization, mitotic arrest, } \\
\text { antiangiogenic activity, and inhibition of cell } \\
\text { proliferation. }\end{array}$ & $\begin{array}{l}{[26,} \\
27]\end{array}$ \\
\hline
\end{tabular}




\begin{tabular}{|c|c|c|c|c|c|}
\hline $\begin{array}{l}\text { FA-conjugated poly(ester amine) (FP-PEA) } \\
\text { complexed with TAM67 gene (FP-PEA/TAM67 } \\
\text { polyplexes) }\end{array}$ & TAM67 gene & $\begin{array}{l}\text { KB tumor-bearing } \\
\text { BALB/c nude mice }\end{array}$ & i.t. & $\begin{array}{l}\text { - FR-PEA/TAM67 polyplexes inhibited the } \\
\text { tumor growth by suppressing cell } \\
\text { proliferation in the tumor. }\end{array}$ & {$[28]$} \\
\hline $\begin{array}{l}\text { siRNA-loaded FA-PEG-chitosan oligosaccharide } \\
\text { lactate NPs (siRNA/FA-PEG-COL) }\end{array}$ & $\begin{array}{l}\text { siRNA against } \\
\text { HIF- } 1 \alpha\end{array}$ & $\begin{array}{l}\text { OVK18\#2 ovarian } \\
\text { tumor-bearing BALB } \\
\text { nude mice }\end{array}$ & i.v. & $\begin{array}{l}\text { FA-PEG-COL NPs possessed superior } \\
\text { compatibility with erythrocytes in terms of } \\
\text { degree of aggregation and hemolytic } \\
\text { activity. } \\
\text { - FA-PEG-COL NPs showed significant } \\
\text { greater tumor accumulation than } \\
\text { non-targeted COL NPs. }\end{array}$ & {$[29]$} \\
\hline FA-PEG-chitosan-graft-polyethylenimine (FPCP) & $\begin{array}{l}\text { GFP plasmid } \\
\text { and } \\
P d c d 4 \text { plasmid }\end{array}$ & $\begin{array}{l}\mathrm{H}-\operatorname{ras} 12 \mathrm{~V} \text { transgenic } \\
\text { mice }\end{array}$ & i.v. & $\begin{array}{l}\text { FPCP/GFP complexes showed high levels of } \\
\text { GFP expression in liver cancer tissues } \\
\text { compared with GFP alone and PEI/GFP } \\
\text { complexes. } \\
\text { FPCP/Pdcd } 4 \text { complexes showed a } \\
\text { significant decrease in tumor numbers } \\
\text { compared with Pdcd } 4 \text { alone but not } \\
\text { PEI-Pdcd } 4 \text { complexes. }\end{array}$ & {$[30]$} \\
\hline $\begin{array}{l}\text { 2-hydroxypopyl- } \beta \text {-cyclodextrin (HP- } \beta \text {-CD) and FA } \\
\text { cross-linked with low molecular weight } \\
\text { polyethyleneimine (FA-HP- } \beta \text {-CD-PEI) }\end{array}$ & $\begin{array}{l}\text { siRNA against } \\
\text { VEGF }\end{array}$ & $\begin{array}{l}\text { HeLa tumor-bearing } \\
\text { nude mice }\end{array}$ & i.v. & $\begin{array}{l}\text { Four doses of FA-HP- } \beta \text {-CD-PEI/siVEGF } \\
\text { polyplexes reduced tumor growth by } \\
\text { decreasing VEGF expression in the tumor, } \\
\text { compared to the ones treated with } \\
\text { HP- } \beta-C D-P E I / s i V E G F \text { polyplexes. }\end{array}$ & {$[31]$} \\
\hline $\begin{array}{l}\text { FA-decorated ethylenediamine-surface modified } \\
\text { fullerene (C60-PEI-FA) }\end{array}$ & $\begin{array}{l}\text { Docetaxel } \\
\text { (DTX) }\end{array}$ & $\begin{array}{l}\text { S180 tumor-bearing } \\
\text { BALB/c mice }\end{array}$ & i.v. & $\begin{array}{l}\text { Administration of C60-PEI-FA/DTX every } \\
2 \text { days significantly inhibited tumor growth, } \\
\text { compared to untreated, C60-PEI-FA-, free } \\
\text { DTX-, C60-PEI/DTX-treated mice }\end{array}$ & {$[32]$} \\
\hline $\begin{array}{l}\text { Docetaxel encapsulated PLGA-lecithin-PEG } \\
\text { core-shell NPs } \\
\text { (FT-NP DTX) }\end{array}$ & $\begin{array}{l}\text { Docetaxel } \\
(\mathrm{DTX})\end{array}$ & $\begin{array}{l}\text { KB tumor-bearing } \\
\text { nude mice }\end{array}$ & i.v. & $\begin{array}{l}\text { The radiosensitization efficacy of FT-NP } \\
\text { DTX is dependent on the timing of } \\
\text { radiotherapy. } \\
\text { Free DTX, FT-NP DTX and non-targeted } \\
\text { NP DTX (NT-NP DTX) led to significant }\end{array}$ & {$[33]$} \\
\hline
\end{tabular}




\begin{tabular}{|c|c|c|c|c|c|}
\hline & & & & $\begin{array}{l}\text { tumor growth delay when tumors were } \\
\text { irradiated, but FT-NP DTX produced the } \\
\text { maximum tumor growth delay, which was } \\
\text { significantly different from NT-NP DTX. }\end{array}$ & \\
\hline $\begin{array}{l}\text { FA-modified stealthy PEOz corona micelles } \\
\text { (FA-PEOz-PCL) }\end{array}$ & $\begin{array}{l}\text { Doxorubicin } \\
(\mathrm{DOX})\end{array}$ & $\begin{array}{l}\text { KB tumor-bearing } \\
\text { BALB/c nude mice }\end{array}$ & i.v. & $\begin{array}{l}\text { DOX entrapped FA-PEOz-PCL micelles } \\
\text { effectively inhibited the tumor growth and } \\
\text { reduced the toxicity to mice compared with } \\
\text { free DOX. }\end{array}$ & [34] \\
\hline $\begin{array}{l}\text { FA and paclitaxel loaded polymeric micelles } \\
\text { [FA-M(PTX)] prepared by co-assembling } \\
\text { FA-polymer conjugate [MPEG-b-P(LA-co-DHP/FA)] } \\
\text { and PTX-polymer conjugate } \\
{[\text { MPEG-b-P(LA-co-MCC/PTX)] }}\end{array}$ & $\begin{array}{l}\text { Paclitaxel } \\
(\text { PTX) }\end{array}$ & $\begin{array}{l}\text { EC9706 esophageal } \\
\text { tumor-bearing nude } \\
\text { mice }\end{array}$ & i.v. & $\begin{array}{l}\text { FA-M(PTX) micelles efficiently inhibited } \\
\text { tumor growth and extended the survival rate } \\
\text { of the mice, compared to free PTX and } \\
\text { non-targeted M(PTX) micelles. }\end{array}$ & [35] \\
\hline $\begin{array}{l}\text { Folate-decorated biodegradable polymeric micelles } \\
\text { [FA-M(Pt)] prepared by co-assembling FA-polymer } \\
\text { conjugate (FA-PEG-PLA) and diaminocyclohexane } \\
\text { platinum (DACH-Pt) of oxaliplatin-polymer complex } \\
\text { [mPEG-b-P(LA-co-MCC/Pt)] }\end{array}$ & Oxaliplatin & $\begin{array}{l}\text { H22 liver } \\
\text { tumor-bearing } \\
\text { Kunming mice }\end{array}$ & i.v. & $\begin{array}{l}\text { FA-M(Pt) effectively inhibited the tumor } \\
\text { growth and prolonged the survival rate of } \\
\text { the mice, compared to non-targeted } \mathrm{M}(\mathrm{Pt}) \\
\text { and free oxaliplatin. }\end{array}$ & [36] \\
\hline $\begin{array}{l}\text { FA-conjugated carboxymethyl lauryl } \\
\text { chitosan/superparamagnetic iron oxide } \\
\text { (FA-CLC/SPIO) micelles }\end{array}$ & $\begin{array}{l}\text { Chlorin e6 } \\
(\mathrm{Ce} 6)\end{array}$ & $\begin{array}{l}\text { Hela tumor-bearing } \\
\text { nude mice }\end{array}$ & i.v. & $\begin{array}{l}\text { Targeted sensitization-enhanced } \\
\text { radiotherapy (TSER: Ce6-loaded } \\
\text { FA-CLC/SPIO micelles and US/XR } \\
\text { treatment) greatly inhibited tumor growth; } \\
\text { whereas free Ce6 and US/XR, alone or } \\
\text { together, did not substantially inhibited } \\
\text { tumor growth. } \\
\text { - TSER markedly decreased level of nuclear } \\
\text { integrity in the tumor. } \\
\text { No abnormalities (i.e., within normal ranges } \\
\text { of ALT, AST, BUN and CREA) were } \\
\text { observed in liver or kidney function in the } \\
\text { TSER-treated mice. }\end{array}$ & [37] \\
\hline Poly(propylene sulfide)-PEG-serine-folic acid & Zinc & HepG2 tumor-bearing & i.v. & - PPS-mPEG-Ser-FA@DOX@ZNPC & [38] \\
\hline
\end{tabular}




\begin{tabular}{|c|c|c|c|c|c|}
\hline (PPS-mPEG-Ser-FA) emulsified micelles & $\begin{array}{l}\text { phthalocyanine } \\
\text { (ZNPC) and } \\
\text { doxorubicin } \\
\text { (DOX) }\end{array}$ & nude mice & & $\begin{array}{l}\text { micelles with irradiation induced the } \\
\text { greatest tumor suppression. } \\
\text { - Laser irradiation enhanced tumor } \\
\text { accumulation of DOX, disassociation of } \\
\text { micelles, and release of DOX. } \\
\text { PPS-mPEG-Ser-FA micelles significantly } \\
\text { reduce the toxic side effect of DOX for the } \\
\text { treatment. }\end{array}$ & \\
\hline $\begin{array}{l}\text { Docetaxel and cisplatin-encapsulated liquid } \\
\text { crystalline NPs formed by } \\
\text { hydroxypropyl- } \beta \text {-cyclodextrin mixed with } \\
\text { chitosan-PEG-folic acid (FA-LCN/DC) }\end{array}$ & $\begin{array}{l}\text { Docetaxel } \\
\text { (DOC) and } \\
\text { cisplatin (CIS) }\end{array}$ & $\begin{array}{l}\text { MDA-MB-231 } \\
\text { tumor-bearing Balb/c } \\
\text { nude mice }\end{array}$ & i.v. & $\begin{array}{l}\text { The inhibition of tumor growth was greater } \\
\text { in mice treated with FA-LCN/DC than those } \\
\text { with DOC, CIS, and DC cocktail. } \\
\text { The survival rate of mice treated with } \\
\text { FA-LCN/DC was higher than those with } \\
\text { control, DOC, CIS, and DC cocktail. } \\
\text { The tumor caspase-3 and RARP expression } \\
\text { levels were elevated and Ki-67 and CD31 } \\
\text { were reduced in the mice treated with } \\
\text { FA-LCN/DC than those with DOC, CIS, and } \\
\text { DC cocktail. }\end{array}$ & [39] \\
\hline $\begin{array}{l}\text { FA-PEG-PCL and MPEG-PCL emulsified NPs } \\
\text { (FANPs) }\end{array}$ & DiR dye & $\begin{array}{l}\text { A549 tumore-bearing } \\
\text { nude mice }\end{array}$ & i.v. & $\begin{array}{l}\text { The tumor accumulation of FANP in DTX } \\
\text { treated tumor was higher than untreated } \\
\text { tumor on the same mouse. } \\
\text { - Pretreatment with DTX largely enhanced the } \\
\text { accumulation of NP and FANP in tumor } \\
\text { sites, and the fluorescent intensity in FANP } \\
\text { group was } 1.2 \text { fold higher than NP group. } \\
\text { - The fluorescence mainly focused in liver } \\
\text { and spleen. }\end{array}$ & [40] \\
\hline $\begin{array}{l}\text { FA and 1,2-dicarboxylic-cyclohexene anhydride } \\
\text { (DCA)-functionalized } \\
\text { n-butylamine-poly(L-lysine)-b-poly(L-cysteine) } \\
\text { ( FA-PLL(DCA)-PLC) NPs (charge-reversible }\end{array}$ & $\begin{array}{l}\text { Doxorubicin } \\
(\mathrm{DOX})\end{array}$ & $\begin{array}{l}\text { Hela tumor-bearing } \\
\text { nude mice }\end{array}$ & i.v. & $\begin{array}{l}\text { The amount of DOX accumulated in tumors } \\
\text { treated with DOX-loaded FD-NPs was much } \\
\text { higher than that with free DOX and } \\
\text { DOX-loaded FS-NPs. }\end{array}$ & [41] \\
\hline
\end{tabular}




\begin{tabular}{|c|c|c|c|c|c|}
\hline $\begin{array}{l}\text { FD-NPs) and negatively charged FA-PLL(succinic } \\
\text { anhydride)-PLC NPs (FS-NPs) }\end{array}$ & & & & & \\
\hline $\begin{array}{l}\text { FA-decorated self-organized NPs fabricated by } \\
\text { complexation of doxorubicin-conjugated dextran } \\
\text { with FA-grafted chitosan (FADex NPs) }\end{array}$ & $\begin{array}{l}\text { Doxorubicin } \\
\text { (DOX) }\end{array}$ & $\begin{array}{l}\text { KB tumor-bearing } \\
\text { BALB/c nude mice }\end{array}$ & i.v. & $\begin{array}{l}\text { Two doses of FADex NPs efficiently } \\
\text { suppressed the tumor growth, compared to } \\
\text { non-targeted PEGylated NPs (CPDex NPs) } \\
\text { and free DOX. } \\
\text { This tumor growth suppression was } \\
\text { significantly prohibited in the presence of } \\
\text { free FA ( } 2 \mathrm{mM} \text { ), as the tumor growth } \\
\text { tendency of FADex NPs and FA-treated } \\
\text { mice became similar to the one of CPDex } \\
\text { NPs-treated mice. }\end{array}$ & {$[42]$} \\
\hline $\begin{array}{l}\text { pH-sensitive FA-PEG-chitosan-PAMAM-plasmid } \\
\text { DNA polyplexes (FPCPHDs) }\end{array}$ & RFP plasmid & $\begin{array}{l}\text { S180 tumor-bearing } \\
\text { BALB/c nude mice }\end{array}$ & i.v. & $\begin{array}{l}\text { FPCPHDs significantly increased RFP } \\
\text { expression at the tumor site, compared to } \\
\text { non-targeted PDs, PHDs, CPHDs, and } \\
\text { PCPHDs polyplexes. }\end{array}$ & {$[43]$} \\
\hline $\begin{array}{l}\text { Self-assembled polyelectrolyte polyplexes of } \\
\text { folate-dextran-siRNA via disulfide bonds and linear } \\
\text { polyethylenimine (folate-DSC/LPEI/siRNA) }\end{array}$ & $\begin{array}{l}\text { siRNA against } \\
\text { GFP (siGFP) }\end{array}$ & $\begin{array}{l}\text { GFP } \\
\text { overexpressing-HeLa } \\
\text { tumor-bearing nude } \\
\text { mice }\end{array}$ & i.v. & $\begin{array}{l}\text { Folate-DSC/LPEI/siGFP efficiently } \\
\text { suppressed GFP expression in tumor, } \\
\text { compared to PBS and non-targeted } \\
\text { DSC/LPEI/siGFP. }\end{array}$ & {$[44]$} \\
\hline $\begin{array}{l}\text { A molecular hydrogelator system of FA-Taxol } \\
\text { conjugates formed by glutathione }\end{array}$ & Taxol & $\begin{array}{l}\text { 4T1-luciferase breast } \\
\text { tumor-bearing mice }\end{array}$ & i.t. & $\begin{array}{l}\text { A single dose of i.t. injection of FA-Taxol } \\
\text { hydrogel more efficiently inhibited tumor } \\
\text { growth than four doses of i.v. injection of } \\
\text { free Taxol. }\end{array}$ & {$[45]$} \\
\hline $\begin{array}{l}\text { A FR-targeted rhaponticin (FRHA) synthesized via a } \\
\text { releasable disulfide linker }\end{array}$ & $\begin{array}{l}\text { Rhaponticin } \\
\text { (RHA) }\end{array}$ & $\begin{array}{l}\text { FR-positive KB and } \\
\text { M109 tumor-bearing } \\
\text { Balb/c mice } \\
\text { FR-negative } 4 \mathrm{~T} 1 \\
\text { tumor-bearing Balb/c } \\
\text { mice }\end{array}$ & i.v. & $\begin{array}{l}\text { Administration of FRHA to KB and M109 } \\
\text { tumor-bearing mice three times per week } \\
\text { significantly inhibited tumor growth, } \\
\text { compared to PBS and free RHA treatment. } \\
\text { Administration of FRHA to 4T1 } \\
\text { tumor-bearing mice failed to suppress tumor } \\
\text { growth. }\end{array}$ & [46] \\
\hline Folate-appended methyl- $\beta$-cyclodextrin & FA-M- $\beta-\mathrm{CyD}$ & Colon-26 & i.t. & - FA-M- $\beta$-CyD drastically inhibited the tumor & [47] \\
\hline
\end{tabular}




\begin{tabular}{|c|c|c|c|c|c|}
\hline$(\mathrm{FA}-\mathrm{M}-\beta-\mathrm{CyD})$ & & $\begin{array}{l}\text { tumor-bearing } \\
\text { BALB/c mice }\end{array}$ & i.v. & $\begin{array}{l}\text { growth, compared to control, doxorubicin, } \\
\text { and non-targeted M- } \beta-\mathrm{CyD} \text {. } \\
\text { All of the tumor-bearing mice treated with } \\
\text { FA-M- } \beta \text {-CyD survived for at least } 140 \text { days; } \\
\text { whereas the others only survived for around } \\
60 \text { days. } \\
\text { FA-M- } \beta-C y D \text { treated mice showed no } \\
\text { significant change in blood chemistry } \\
\text { values, including creatinine, blood urea } \\
\text { nitrogen, aspartate aminotransferase, alanine } \\
\text { aminotransferase, and lactate } \\
\text { dehydrogenase. }\end{array}$ & \\
\hline FA-anchored cucumber mosaic virus (FA-CMV) & $\begin{array}{l}\text { Doxorubicin } \\
(\mathrm{DOX})\end{array}$ & $\begin{array}{l}\text { OVCAR-3 } \\
\text { tumor-bearing } \\
\text { BALB/c nude mice }\end{array}$ & i.p. & $\begin{array}{l}\text { Administration of FA-CMV-DOX every five } \\
\text { days significantly decreased the } \\
\text { accumulation of DOX in mouse myocardial } \\
\text { cells but increased the uptake of DOX in the } \\
\text { ovarian cancer cells in tumor tissue, } \\
\text { compared to negative control, free DOX, } \\
\text { and CMV-DOX treatment. } \\
\text { FA-CMV-DOX induced less cardiotoxicity } \\
\text { and enhanced antitumor effect. }\end{array}$ & [48] \\
\hline $\begin{array}{l}\text { FA-conjugated single-walled carbon nanotubes } \\
\text { complexed with docosanol-conjugated paclitaxel } \\
\text { (FA-SWNT-lipid-PTX) }\end{array}$ & $\begin{array}{l}\text { Paclitaxel } \\
\text { (PTX) }\end{array}$ & $\begin{array}{l}\text { MCF-1 breast } \\
\text { tumor-bearing nude } \\
\text { mice }\end{array}$ & i.v. & $\begin{array}{l}\text { Four doses of FA-SWNT-lipid-PTX } \\
\text { significantly suppressed tumor growth, } \\
\text { compared to free PTX and PBS control. } \\
\text { No mortality and adverse effect was } \\
\text { observed in SWNT-lipid-PTX-treated mice. } \\
\text { - Hematologic assessment (hematocrit, } \\
\text { hemoglobin, red blood cell count and white } \\
\text { blood cell count) and histological staining } \\
\text { (liver, heart, lung, and kidney) showed no } \\
\text { difference between control and } \\
\text { SWNT-lipid-PTX-treated mice. }\end{array}$ & [49] \\
\hline
\end{tabular}




\begin{tabular}{|c|c|c|c|c|c|}
\hline $\begin{array}{l}\text { Folate-decorated poly(ethylene } \\
\text { oxide)- } b \text {-poly(methacrylic acid)-cross-linked } \\
\text { nanogels (FA-nanogels) }\end{array}$ & $\begin{array}{l}\text { Cisplatin } \\
(\mathrm{CDDP}) \\
\text { Doxorubicin } \\
(\mathrm{DOX})\end{array}$ & $\begin{array}{l}\text { A2780 ovarian } \\
\text { tumor-bearing nude } \\
\text { mice }\end{array}$ & i.v. & $\begin{array}{l}\text { Tumor uptake of FA-nanogels was } \\
\text { significantly higher than free CDDP and } \\
\text { non-targeted nanogels at } 4 \text { days } \\
\text { post-injection. } \\
\text { - The increased uptake was significantly } \\
\text { reversed by co-administration of free FA. } \\
\text { - Administration of FA-nanogel/CDDP every } \\
\text { four days significantly reduced tumor } \\
\text { growth, compared to dextrose, nanogel } \\
\text { alone, free CDDP, non-targeted } \\
\text { nanogel/CDDP, and FA-nanogel/CDDP with } \\
\text { free FA treatment. }\end{array}$ & {$[50]$} \\
\hline $\begin{array}{l}\text { Doxorubicin-loaded folate-decorated silica } \\
\text { nanorattles (DOX-FA-SNs) }\end{array}$ & $\begin{array}{l}\text { Doxorubicin } \\
(\mathrm{DOX})\end{array}$ & $\begin{array}{l}\text { HeLa tumor-bearing } \\
\text { BALB/c nude mice }\end{array}$ & i.v. & $\begin{array}{l}\text { Near infrared-labeled FA-SNs } \\
\text { (ICG-FA-SNs) were distributed into the } \\
\text { tumor at } 4 \text { hours post-injection and retained } \\
\text { in the tumor up to } 24 \text { hours. } \\
\text { Administration of DOX-FA-SNs every three } \\
\text { days significantly suppressed tumor growth, } \\
\text { compared to control, FA-SNs alone, free } \\
\text { DOX, and non-targeted DOX-SNs }\end{array}$ & [51] \\
\hline
\end{tabular}

Abbreviations: SCID, severe combined immunodeficiency; NPs, nanoparticles; FA, folic acid; FR, folate receptor; PEG, polyethylene glycol; GFP, green fluorescence protein; RFP, red fluorescence protein; i.v., intravenous; i.t., intratumoral; i.p., intraperitoneal. 
To understand the mechanism of cellular uptake and the specificity to the FR, investigators challenged FA-conjugated nanoparticles with free FA in FR highly or negatively expressed cancer cell lines. For example, FA-coupled PEGylated nano-paclitaxel liposome (FA-NP) was developed to reverse drug resistance in paclitaxel-resistant (SKOV3/TAX) ovarian cancer [24]. FA-NP markedly inhibited the growth of ovarian cancer cells and caused more $\mathrm{G}_{2} / \mathrm{M}$ cell cycle arrest and apoptotic changes in ovarian cancer cells than NP or free paclitaxel. However, these effects were blunted in the presence of free FA $(1 \mathrm{mM})$, which competitively inhibited the receptor-mediated uptake of FA-NP. A separate study also revealed that the presence of FA within the cholesterol domain could enhance liposome-based transfection in cultured KB cells [52]. Zeng et al. developed FA-decorated poly(ethylene oxide)-b-poly(methacrylic acid)-cross-linked nanogels (FA-nanogels) to load cisplatin or doxorubicin. The cellular uptake of FA-nanogels in human ovarian carcinomas FR-positive A2780 cells greatly exceeded that of the non-targeted nanogels. However, the cellular uptake of FA-nanogels only reached about 50\% of the initial in the presence of $0.5 \mathrm{mM}$ FA and was further suppressed to $20-25 \%$ of the initial in the presence of $10 \mathrm{mM}$ FA [50]. Similarly, it was shown that pre-treatment or the presence of free FA (1-2 mM) significantly reduced the cellular uptake or the cytotoxicity potency of FA-conjugated nanomedicines including FA-appended methyl-b-cyclodextrin (FA-M- $\beta$-CyD), FA-anchored cucumber mosaic virus (FA-CMV), or FA-decorated self-organized NPs (FADex NPs) $[42,47,48]$.

In addition to chemotherapeutic drug, FA-conjugated nanoparticles, particularly 
FA-modified dendrimers, have been explored for targeted gene delivery to FR highly expressed tumors. For example, a pH-sensitive FA-PEG-chitosan-PAMAM-plasmid DNA complexes (FPCHDs) were designed for cancer cell targeting gene delivery [43]. FPCPHDs were prepared by a pH-sensitive core-shell system, which contains PEG tethered carboxylated chitosan modified FA, PAMAM dendrimer generation 4, high mobility group box 1 (HMGB1), and plasmid DNA. FPCPHDs were shown to significantly enhance luciferase activity and red fluorescence protein (RFP) expression in KB cells, compared to non-targeted nanocomplexes. However, such enhancement could be significantly inhibited by pre-treatment of free FA (1 mM). Intracellular trafficking of FPCPHDs in KB cells showed that FPCPHDs rapidly escaped from endo-lysosomes and exclusively located in the nucleus at $3 \mathrm{~h}$ post transfection. Similarly, the presence of free FA was also shown to drastically decrease the transfection efficiency of FA-conjugated polyplexes, such as FA-conjugated poly(ester amine) (FP-PEA)/plasmid polyplexes and folate-dextran-siRNA/linear polyethylenimine (folate-DSC/LPEI) polyplexes [28, 44].

In our recent study, we found FA-decorated PAMAM dendrimer generation 4 (G4-FA) facilitated the cellular uptake of dendrimers and dendrimer/plasmid polyplexes in a FR-dependent manner. Free FA dose-dependently suppressed the cellular uptake of G4-FA for the same binding site, that is, FR, on the surface of head and neck cancer cells. Furthermore, we found G4-FA was preferentially taken up by HN12 (FR-high) but not U87 (FR-low) cells in a co-culture model. As a result, G4-FA showed a higher cytocompatibility and transfection 
efficiency than none targeted dendrimer in FR-high cells such as HN12 and T98 [53].

The binding constant of the free folate with FR has been reported as 0.01-1 nM [54, 55]. the reported concentration for free FA to compete with FA-conjugated nanoparticles were $1 \mathrm{mM}$ or more, suggesting that FA-conjugated nanoparticles possessed higher binding affinities to cellular FR than free FA. Such encouraging property may be beneficial for nanoparticles to compete free folate for FR targeting in vivo. On the other hand, increasing FA moieties may not further improve cellular uptake of nanoparticles [56]. For example, an optimal amount of FA moieties (0.1-0.2 $\mu \mathrm{mol} \mathrm{FA} / \mathrm{mg}$ polymer) was reported, above which the uptake of FA-nanogels was gradually decreased [50]. Similarly, we found excess amount of G4-FA conjugates could suppress the cellular uptake of conjugates themselves, most likely due to the saturation of FR on the cell surface [53]. The fundamental understanding of FA-conjugated nanoparticles as targeting vectors can help investigators to better design drug delivery systems for the cancers with high FR expression.

\section{Pharmacokinetics (PK) of FA-decorated NPs}

Pharmacokinetics (PK) and pharmacodynamics (PD) of drug is routinely investigated in early clinical studies to determine the absorption, distribution, metabolism and excretion of the drug. The PK study of targeted nanomedicines may be also relevant to determine drug concentration within a target tissue such as tumor [57]. A disulfide FR-targeted rhaponticin (FRHA) was synthesized via tethering the thiol-activated FA-spacer to thiol-reactive derivate of 
rhaponticin (RHA) to improve anticancer therapeutic efficacy of RHA [46]. The mouse PK profiles of RHA showed that FRHA was rapidly removed from systemic circulation after its i.v. administration to M109 (FR-positive) tumor-bearing mice (half-life about 10 min) but much slower to those 4T1 (FR-negative) tumor bearing mice and normal mice (half-life over $150 \mathrm{~min}$ ), suggesting FRHA was rapidly taken up by FR-positive tumor following i.v. administration.

FR-targeted docetaxel (DTX)-lipid-based-nanosuspensions (tLNS) were proposed for active-targeted cancer therapy [21]. The PK profiles of DTX in a B16 tumor-bearing mouse model showed that the DTX serum concentration remained measurable at 12 hours-post i.v. administration of tLNS and non-targeted docetaxel-lipid-based-nanosuspensions (pLNS) but not free Duopafei group. Compared to the Duopafei administration, tLNS and pLNS significantly increased the area under the plasma concentration-time (AUC) by 1.59 and 1.66 times, respectively; prolonged the mean residence time (MRT) by 2.40 and 2.41 times, respectively; and decreased the plasma clearance rate (CL). The overall targeting efficiency of pLNS was 1.09 times better than that of Duopafei; whereas the targeting efficiency of tLNS was 1.13 times better than that of pLNS.

FA-decorated biodegradable polymeric micelles [FA-M(Pt)] were prepared by coassembling FA-polymer conjugate (FA-PEG-PLA) and diaminocyclohexane platinum (DACH-Pt) of oxaliplatin-polymer complex [mPEG-b-P(LA-co-MCC/Pt)] for cancer therapy [36]. The PK profiles of $\mathrm{Pt}$ in a $\mathrm{KB}$ tumor-bearing mouse model showed that $\mathrm{FA}-\mathrm{M}(\mathrm{Pt})$ possessed greater steady-state AUC, slower CL, and longer MRT than free oxaliplatin. M(Pt) had higher plasma Pt 
concentration within $4 \mathrm{~h}$; whereas $\mathrm{FA}-\mathrm{M}(\mathrm{Pt})$ had higher plasma concentration after $4 \mathrm{~h}$. Compared to $\mathrm{M}(\mathrm{Pt})$, FA-M(Pt) showed a bigger AUC, slower CL, but same MRT. FA-M(Pt) was not as good as $\mathrm{M}(\mathrm{Pt})$ in respect of the plasma drug concentration, presumably due to the enhanced interaction between the FA moieties on the micelles and the blood proteins compared to the case of $\mathrm{M}(\mathrm{Pt})$ which were only PEGylated to prolong the circulation time.

FA-decorated ethylenediamine-surface modified fullerene (C60-PEI-FA) was synthesized for tumor-targeted delivery of docetaxel (DTX) [32]. The PK profiles of DTX in an S180 tumor mouse model showed that C60-PEI-FA/DTX significantly increased the blood circulation time of DTX with an increase of AUC and MRT by 2 and 6 times, respectively, compared to free DTX. Meanwhile, the uptake of DTX in tumor was significantly higher in C60-PEI-FA/DTX-treated mice than in C60-PEI/DTX and DTX-treated mice. All these findings provide strong evidence in rational design of FR-targeted nanomedicines based upon the improved PK profiles.

\section{Administration routes of FR-targeted NPs}

The administration routes commonly used to get therapeutic and imaging agents to the tumor include intraperitoneal (i.p.) injection, intratumoral (i.t.) injection, intravenous (i.v.) injection, enteric administration, inhaled administration, etc. A majority of FA-drug conjugates and FR-targeted nanomedicines and imaging nanoprobes are systemically administered via i.v. injection as the ease of application and avoidance of the first pass effect. Following systemic administration, FR-targeted NPs can follow enhanced permeability and retention (EPR) effect 
and FR-mediated endocytosis to get into the tumor. Compared to the systemic administration, local administration such as i.t. injection or convection-enhanced delivery (CED) is more efficacious and precise to deliver therapeutics to the tumor and reduce adverse-effect [58]. FR-targeted nanomedicines can prolong tumor retention time within the tumor microenvironment. However, such local administration is limited by the tumor origin. Inhaled and enteric drug administrations of FR-targeted nanomedicines have been investigated recently as alternative non-invasive administration routes. For example, FA-PEG-hydrophobically-modified dextran (F-PEG-HMD) micelles were developed for FR-expressing lung tumor drug delivery via pulmonary administration [59]. Spray-drying was applied to obtain dry powders embedding the paclitaxel-loaded F-PEG-HMD micelles. In the M109-HiFR murine orthotopic lung tumor mouse model, F-PEG-HMD micelles reached the lung tumor site and consequently distributed into the lung tumor with no sign of lung toxicity and inflammation after pulmonary administration.

As another example, mesoporous silica NPs (MSNs) functionalized with PEG, PEI, and FA were developed for colon cancer and inflammation drug delivery via enteric administration [60]. In an $18 \mathrm{FVB} / \mathrm{N}$ mouse model, the number of intestinal goblet cell differentiation in the colon of mice given $\gamma$-secretase inhibitor (DAPT)/FA-PEG-PEI-MSNs were significantly higher than DAPT alone, DAPT/FA-PEI-MSNs, and FA-PEG-PEI-MSNs after gavage. This formulation offers an alternate route for the long-term non-invasive management of intestinal diseases such as colon cancer and inflammation. 


\section{FR-targeted NPs for tumor diagnostics and theranostics}

Nanotechnology has been extensively applied to improve tumor imaging and diagnostics, including near-infrared (NIR) fluorescence imaging, magnetic resonance imaging (MRI), computed tomography (CT), ultrasonic imaging. NIR fluorescence imaging becomes a highly sensitive, non-invasive, non-radiant technique for real-time in vivo monitoring of biological information [61]. In addition to therapeutic agent delivery, FA has been widely used for the selective delivery of attached imaging agents. Major recent findings using FR-targeted nanoprobes for in vivo tumor imaging were summarized in Table 2. By combination, an MRI guided photothermal-chemotherapy was developed as a theranostic nanoplatform [62]. Gadolinium (Gd) NPs were decorated onto grapheme oxide (GO) to form GO@Gd nanocomposites, which were then functioned by PEG and FA and loaded with DOX to form GO@Gd-PEG-FA/DOX NPs. In an S180 tumor-bearing mouse model, GO@Gd-PEG-FA/DOX greatly enhanced the uptake of DOX in tumor compared to GO@Gd-PEG/DPX and free DOX at all the time after i.v. administration.GO@Gd-PEG-FA exhibited a good tumor-targeting property and a strong $\mathrm{T}_{1}$-weighted MRI ability. Under the guidance with MRI imaging, synergistic treatment of GO@Gd-PEG-FA/DOX with NIR irradiation significantly enhanced the antitumor effect compared to free DOX, GO@Gd-PEG/DOX, GO@Gd-PEG-FA/DOX. 
Table 2. Major preclinical findings using FR-targeted nanoprobes for tumor imaging

\begin{tabular}{|c|c|c|c|c|c|}
\hline Nanoprobe & $\begin{array}{l}\text { Imaging } \\
\text { technique }\end{array}$ & Model & Route & Major in vivo findings & Ref. \\
\hline $\begin{array}{l}\text { Self-assembly NPs of the heparin-FA } \\
\text { conjugates and NIR fluorescence dye-780 } \\
\text { (HF-IR-780 NPs) }\end{array}$ & $\begin{array}{l}\text { NIR } \\
\text { fluorescence } \\
\text { imaging }\end{array}$ & $\begin{array}{l}\text { MCF-7 } \\
\text { tumor-bearing nude } \\
\text { mice }\end{array}$ & i.v. & $\begin{array}{l}\text { - The fluorescence signal in the tumor was detected } \\
\text { at } 3 \mathrm{~h} \text { post-injection, and the signal intensity was } \\
\text { observed much stronger in tumor tissue than that in } \\
\text { lung and liver at } 72 \mathrm{~h} \text { post-injection. } \\
\text { - HF-IR-780 NPs treated mice showed stronger } \\
\text { fluorescence intensity in the tumor tissue than free } \\
\text { IR-780 in the excised tissue evaluation at } 72 \mathrm{~h} \\
\text { post-injection. }\end{array}$ & {$[12]$} \\
\hline $\begin{array}{l}\text { FA-modified trypsin-stabilized gold } \\
\text { nanoclusters with NIR fluorescence } \\
\text { (FA-try-AuNCs) }\end{array}$ & $\begin{array}{l}\text { NIR } \\
\text { fluorescence } \\
\text { imaging }\end{array}$ & $\begin{array}{l}\text { Hela tumor-bearing } \\
\text { nude mice }\end{array}$ & $\begin{array}{l}\text { i.t. } \\
\text { s.c. }\end{array}$ & $\begin{array}{l}\text { The fluorescence signal was detected immediately } \\
\text { after i.t. injection of FA-try-AuNCs, and the signal } \\
\text { in the tumor can remain up to } 12 \mathrm{~h} \text {. } \\
\text { - The fluorescence signal was detected all over the } \\
\text { whole body of the mice at } 5 \text { min post-s.c. injection } \\
\text { of FA-try AuNCs, but the signal attanuation in the } \\
\text { tumor site was slower than that in the normal } \\
\text { tissues. }\end{array}$ & {$[63]$} \\
\hline $\begin{array}{l}\text { FA-modified fluorenyl derivative } \\
\text {-encapsulated silica NPs } \\
\text { (SiNP-DFP-PEGFA) }\end{array}$ & $\begin{array}{l}\text { NIR } \\
\text { fluorescence } \\
\text { imaging }\end{array}$ & $\begin{array}{l}\text { HeLa } \\
\text { tumor-bearing nude } \\
\text { mice }\end{array}$ & i.v. & $\begin{array}{l}\text { The fluorescence signal was detected in the tumor } \\
\text { after } 30 \text { min post-injection of SiNP-DFP-PEGFA. } \\
\text { - The tumor fluorescence intensity was steadily } \\
\text { increased and reached its maximum at } 6 \mathrm{~h} \\
\text { post-injection. } \\
\text { - No significant fluorescence signal was detected in } \\
\text { the tumor of the mice injected with } \\
\text { SiNP-DFP-PEG }\end{array}$ & {$[64]$} \\
\hline $\begin{array}{l}\text { Self-assembled NPs with poly- } \gamma \text {-glutamic } \\
\text { acid-FA conjugates and fluorescently labeled } \\
\text { chitosan conjugates with gadolinium } \\
\text { complexed } \\
\text { (PGA-FA/CH-A546-Gd NPs) }\end{array}$ & MRI & $\begin{array}{l}\text { HeLa } \\
\text { tumor-bearing nude } \\
\text { mice }\end{array}$ & i.v. & $\begin{array}{l}\text { - The MRI signal intensity in the tumor site was } \\
\text { increased } 34 \% \text { at } 2 \mathrm{~h} \text { post-injection of } \\
\text { PGA-FA/CH-A546-Gd, compared to the untreated } \\
\text { mice. }\end{array}$ & {$[65]$} \\
\hline
\end{tabular}




\begin{tabular}{|c|c|c|c|c|c|}
\hline $\begin{array}{l}\text { FA-modified PEGylated poly(ethylene } \\
\text { glycol)-poly( } \varepsilon \text {-caprolactone) micelles with } \\
\text { SPIONs-encapsulated } \\
\text { (FA-PEG-PCL-SPIONs) }\end{array}$ & MRI & $\begin{array}{l}\text { BEL-7402 } \\
\text { tumor-bearing nude } \\
\text { mice }\end{array}$ & i.v. & $\begin{array}{l}\text { The change of MRI signal intensity was increased } \\
\text { by } 2.5 \text {-fold in the tumor site at } 3 \mathrm{~h} \text { post-injection of } \\
\text { FA-PEG-PCL-SPIONs, compared to the one of } \\
\text { PEG-PCL-SPIONs treated mice. } \\
\text { - An ideal post-injection time window for MRI } \\
\text { scanning was within } 6 \mathrm{~h} \text { for } \\
\text { FA-PEG-PCL-SPIONs. }\end{array}$ & [66] \\
\hline $\begin{array}{l}\text { Radioiodinated tyrosine-click-FA conjugates } \\
\text { ( }{ }^{125} \text { I-tyrosine-click-folate) }\end{array}$ & CT & $\begin{array}{l}\text { KB tumor-bearing } \\
\text { nude mice }\end{array}$ & i.v. & $\begin{array}{l}\text { The CT signal in both tumor and kidney was } \\
\text { achieved at } 1 \mathrm{~h} \text { post-injection of } \\
{ }^{125} \text { I-tyrosine-click-folate. } \\
\text { Pre-injection of potassium iodide and antifolate } \\
\text { pemetrexed to the mice effectively reduced CT } \\
\text { signal in the non-trageted organs (thyroid gland } \\
\text { and kidney), improving tumor-to-background } \\
\text { contrast. }\end{array}$ & [67] \\
\hline $\begin{array}{l}\text { FA-modified dendrimer-entrapped gold NPs } \\
\text { (Au DENPs-FA) }\end{array}$ & CT & $\begin{array}{l}\text { SPC-A1 } \\
\text { tumor-bearing nude } \\
\text { mice }\end{array}$ & $\begin{array}{l}\text { i.v. } \\
\text { i.t. } \\
\text { i.p. }\end{array}$ & $\begin{array}{l}\text { Au DENPs-FA were uptaken by tumor tissue via } \\
\text { i.v., i.t. or i.p. injection, allowing for effective CT } \\
\text { imaging of tumor. } \\
\text { - Addition to the tumor, a large amount of Au } \\
\text { DENPs-FA was found in kidney, lung, spleen and } \\
\text { liver, allowing these NPs to be cleared through } \\
\text { renal route and reticuloendothelial system. }\end{array}$ & [68] \\
\hline $\begin{array}{l}\text { Gadolinium-loaded Au DENPs-FA } \\
\text { (Gd-Au DENPs-FA) }\end{array}$ & $\begin{array}{l}\text { CT/MR dual } \\
\text { mode }\end{array}$ & $\begin{array}{l}\text { KB tumor-bearing } \\
\text { nude mice }\end{array}$ & i.v. & $\begin{array}{l}\text { Both CT value and MR signal in the tumor site } \\
\text { were increased by } 200 \% \text { and } 152.7 \% \text {, respectively } \\
\text { at } 24 \mathrm{~h} \text { post-injection of Gd-Au DENPs-FA, } \\
\text { compared to the ones of Gd-Au DENPs treated } \\
\text { mice, allowing targeted dual mode CT/MR } \\
\text { imaging of tumors. } \\
\text { These NPs were cleared out from the body at } 96 \mathrm{~h} \\
\text { post-injection. }\end{array}$ & [69] \\
\hline
\end{tabular}

Abbreviations: NPs, nanoparticles; FA, folic acid; i.v., intravenous; i.t., intratumoral; i.p., intraperitoneal; s.c., subcutaneous; NIR, near-infrared; MR, magnetic resonance; CT, computed tomography. 


\section{Discussion and outlook}

FA-decorated nanomedicines and nanoprobes have shown promising treatment outcomes for treating FR-positive tumors in mouse xenograft models. The potencies of these therapies in vivo are highly depended on 1) the pharmacokinetics (PK) and bioavailability of FA-decorated nanoparticles, 2) the binding affinity of FA-decorated nanoparticles to the FR on cancer cell surface, 3 ) the dose of FA-decorated nanoparticles that will saturate the FR on cancer cell surface, 4) the rate of folate receptor-mediated endocytosis of FA-decorated nanoparticles, 5) the release kinetics of drug or gene from the nanoparticle cargos, and 6) the recycling rate of FR back onto cancer cell surface for the next available FA-decorated nanoparticles [70].

One of the drawback of FR-targeted nanomedicines could be the high renal uptake. From the biodistribution evaluations, a large amount of the FA-decorated nanoparticles could be clearly observed in the liver and kidney $[44,67,71]$. Nanoparticles may accumulate in liver, spleen and lung because of their size distribution, i.e., nanoparticles with size of $50-100 \mathrm{~nm}$ tend to accumulate in the liver due to noncontinuous endothelia with vascular fenestrations; nanoparticles with the size of $200-500 \mathrm{~nm}$ tend to accumulate in spleen due to interendothelial cell slits; and microparticles with the size of 2-5 $\mu \mathrm{m}$ tend to accumulate in the capillaries of the lung [72]. Interestingly, nanoparticles only with the size less than $5 \mathrm{~nm}$ can be filtered out by the kidneys [73], which leads to the first logical question why these FA-decorated nanoparticles accumulated in the kidneys. Physiologically, folate binding protein (FBP), including FR $\alpha$, FR $\beta$ 
and the reduced folate carrier (RFC), is highly expressed in the kidneys [74]. FBP that possesses high folate binding affinity is located in the brush board membrane of the proximal tubule cells to participate folate reabsorption from the convoluted proximal tubules [75-78]. Hence, these proximal tubular cells are not directly exposed to the circulated FA-decorated nanoparticles unless they are filtered from glomeruli. The filtration initially occurs at the interface of glomerulus and Bowman's capsule. Filtered molecules or nanoparticles need to pass through three filtration layers, the endothelium, glomerular basement membrane (GBM), and foot processes of the podocytes [79]. The endothelium provides an initial physical barrier that contains a pore size of $80-100 \mathrm{~nm}$ in diameter. The GBM with a high concentration of heparin sulfate in the middle layer provides negatively charge to electrostatically repel negatively charged molecules but attract positively charged molecules or nanoparticles, e.g., dendrimers, from the blood. The foot processes of podocytes with a pore size of $15-20 \mathrm{~nm}$ in diameter provide the last filtration barrier [80, 81].

By understanding the anatomy of the glomerulus and Bowman's capsule, the next question comes to what size, shape, zeta potential or other parameters allow FA-decorated nanoparticles to be filtered from the glomeruli and get reabsorbed or taken up by the proximal tubular epithelial cells. Recently, a folate-antioxidant conjugate (5-hydroxy-Tempo-folate) was synthesized to ameliorate renal ischemia/reperfusion injury (IRI). Such Tempo-folate conjugate was designed to target FR $\alpha$-highly expressed proximal tubular epithelia, where the predominant site of injury occurred during and after IRI [82]. The third question is how to prevent FA-decorated 
nanoparticles to be filtered from glomeruli to prolong the circulation time for systemic targeted chemotherapy, perhaps by increasing the size and PEGylation of the nanoparticles. Further investigations with more carefully designed experiments are needed to answer all these questions.

Chemotherapeutic agents, such as cisplatin, doxorubincin, methotrexate, etc., commonly cause nephrotoxicity, including any combination of glomerular or tubular dysfunction, hypertension and disturbance of the renal function [83, 84]. For example, cisplatin can cause acute kidney injury (AKI) and chronic kidney disease (CKD) by reducing renal perfusion, inducing morphologically necrosis of the terminal portion of the proximal tubule and apoptosis in the distal nephron, and eventually leading to renal failure [85-87]. Doxorubicin can cause Adriamycin (doxorubicin)-associated nephropathy (AAN) by inducing glomerulosclerosis and lead to the CKD [88-90]. Accumulation of FA-decorated nanoparticles containing chemotherapeutic agents in kidneys may increase the risk of impaired renal function. Indeed, it would be important to investigate the renal function, i.e., blood urea nitrogen (BUN), serum creatinine, and glomerular filtration rate (GFR), in addition to the current biocompatibility evaluation settings from these treated mice. Better understanding the biodistribution, toxicity, and renal clearance of FA-decorated nanoparticles/nanomedicines may help to guide FR-targeted strategies to advance anticancer chemotherapy in the (pre)clinical trials. 


\section{References}

[1] S.W. Choi, J.B. Mason, Folate and carcinogenesis: an integrated scheme, J. Nutr., 130 (2000) 129-132.

[2] A.C. Antony, The biological chemistry of folate receptors, Blood, 79 (1992) 2807-2820.

[3] R. Zhao, L.H. Matherly, I.D. Goldman, Membrane transporters and folate homeostasis: intestinal absorption and transport into systemic compartments and tissues, Expert Rev. Mol. Med., 11 (2009) e4.

[4] C. Chen, J. Ke, X.E. Zhou, W. Yi, J.S. Brunzelle, J. Li, E.L. Yong, H.E. Xu, K. Melcher, Structural basis for molecular recognition of folic acid by folate receptors, Nature, 500 (2013) 486-489.

[5] N. Parker, M.J. Turk, E. Westrick, J.D. Lewis, P.S. Low, C.P. Leamon, Folate receptor expression in carcinomas and normal tissues determined by a quantitative radioligand binding assay, Anal. Biochem., 338 (2005) 284-293.

[6] J.F. Ross, P.K. Chaudhuri, M. Ratnam, Differential regulation of folate receptor isoforms in normal and malignant tissues in vivo and in established cell lines. Physiologic and clinical implications, Cancer, 73 (1994) 2432-2443.

[7] C.T. Hsueh, B.J. Dolnick, Altered folate-binding protein mRNA stability in KB cells grown in folate-deficient medium, Biochem. Pharmacol., 45 (1993) 2537-2545.

[8] X.L. Sun, A.C. Antony, Evidence that a specific interaction between an 18-base cis-element in the 5'-untranslated region of human folate receptor-alpha mRNA and a 46-kDa cytosolic trans-factor is critical for translation, J. Biol. Chem., 271 (1996) 25539-25547.

[9] H. Elnakat, M. Ratnam, Distribution, functionality and gene regulation of folate receptor isoforms: implications in targeted therapy, Adv. Drug Deliv. Rev., 56 (2004) 1067-1084.

[10] L.E. Kelemen, The role of folate receptor alpha in cancer development, progression and treatment: cause, consequence or innocent bystander?, Int. J. Cancer, 119 (2006) 243-250.

[11] G. Toffoli, C. Cernigoi, A. Russo, A. Gallo, M. Bagnoli, M. Boiocchi, Overexpression of folate binding protein in ovarian cancers, Int. J. Cancer, 74 (1997) 193-198.

[12] C. Yue, P. Liu, M. Zheng, P. Zhao, Y. Wang, Y. Ma, L. Cai, IR-780 dye loaded tumor targeting theranostic nanoparticles for NIR imaging and photothermal therapy, Biomaterials, 34 (2013) 6853-6861. 
[13] C.P. Leamon, J.A. Reddy, I.R. Vlahov, E. Westrick, A. Dawson, R. Dorton, M. Vetzel, H.K. Santhapuram, Y. Wang, Preclinical antitumor activity of a novel folate-targeted dual drug conjugate, Mol. Pharm., 4 (2007) 659-667.

[14] P.P. Peethambaram, L.C. Hartmann, D.J. Jonker, M. de Jonge, E.R. Plummer, L. Martin, J. Konner, J. Marshall, G.D. Goss, V. Teslenko, P.L. Clemens, L.J. Cohen, C.M. Ahlers, L. Alland, A phase I pharmacokinetic and safety analysis of epothilone folate (BMS-753493), a folate receptor targeted chemotherapeutic agent in humans with advanced solid tumors, Invest. New Drugs, 33 (2015) 321-331.

[15] J.A. Ledermann, S. Canevari, T. Thigpen, Targeting the folate receptor: diagnostic and therapeutic approaches to personalize cancer treatments, Ann. Oncol., 26 (2015) 2034-2043.

[16] A.L. Jackman, D.S. Theti, D.D. Gibbs, Antifolates targeted specifically to the folate receptor, Adv. Drug Deliv. Rev., 56 (2004) 1111-1125.

[17] C.P. Leamon, J.A. Reddy, Folate-targeted chemotherapy, Adv. Drug Deliv. Rev., 56 (2004) 1127-1141.

[18] P.S. Low, A.C. Antony, Folate receptor-targeted drugs for cancer and inflammatory diseases, Adv. Drug Deliv. Rev., 56 (2004) 1055-1058.

[19] Y. Lu, E. Sega, C.P. Leamon, P.S. Low, Folate receptor-targeted immunotherapy of cancer: mechanism and therapeutic potential, Adv. Drug Deliv. Rev., 56 (2004) 1161-1176.

[20] Y. Lu, P.S. Low, Immunotherapy of folate receptor-expressing tumors: review of recent advances and future prospects, J. Control. Release, 91 (2003) 17-29.

[21] L. Wang, M. Li, N. Zhang, Folate-targeted docetaxel-lipid-based-nanosuspensions for active-targeted cancer therapy, Int. J. Nanomedicine, 7 (2012) 3281-3294.

[22] A. Chaudhury, S. Das, R.M. Bunte, G.N. Chiu, Potent therapeutic activity of folate receptor-targeted liposomal carboplatin in the localized treatment of intraperitoneally grown human ovarian tumor xenograft, Int. J. Nanomedicine, 7 (2012) 739-751.

[23] P. Zhao, H. Wang, M. Yu, S. Cao, F. Zhang, J. Chang, R. Niu, Paclitaxel-loaded, folic-acid-targeted and TAT-peptide-conjugated polymeric liposomes: in vitro and in vivo evaluation, Pharm. Res., 27 (2010) 1914-1926.

[24] L. Tong, W. Chen, J. Wu, H. Li, Folic acid-coupled nano-paclitaxel liposome reverses drug resistance in SKOV3/TAX ovarian cancer cells, Anticancer. Drugs, 25 (2014) 244-254. 
[25] M. Wang, J. Li, X. Li, H. Mu, X. Zhang, Y. Shi, Y. Chu, A. Wang, Z. Wu, K. Sun, Magnetically and $\mathrm{pH}$ dual responsive dendrosomes for tumor accumulation enhanced folate-targeted hybrid drug delivery, J. Control. Release, 232 (2016) 161-174.

[26] X. Wang, J. Li, Y. Wang, K.J. Cho, G. Kim, A. Gjyrezi, L. Koenig, P. Giannakakou, H.J. Shin, M. Tighiouart, S. Nie, Z.G. Chen, D.M. Shin, HFT-T, a targeting nanoparticle, enhances specific delivery of paclitaxel to folate receptor-positive tumors, ACS Nano, 3 (2009) 3165-3174.

[27] X. Wang, J. Li, Y. Wang, L. Koenig, A. Gjyrezi, P. Giannakakou, E.H. Shin, M. Tighiouart, Z.G. Chen, S. Nie, D.M. Shin, A folate receptor-targeting nanoparticle minimizes drug resistance in a human cancer model, ACS Nano, 5 (2011) 6184-6194.

[28] R.B. Arote, S.K. Hwang, H.T. Lim, T.H. Kim, D. Jere, H.L. Jiang, Y.K. Kim, M.H. Cho, C.S. Cho, The therapeutic efficiency of FP-PEA/TAM67 gene complexes via folate receptor-mediated endocytosis in a xenograft mice model, Biomaterials, 31 (2010) 2435-2445.

[29] T.S. Li, T. Yawata, K. Honke, Efficient siRNA delivery and tumor accumulation mediated by ionically cross-linked folic acid-poly(ethylene glycol)-chitosan oligosaccharide lactate nanoparticles: for the potential targeted ovarian cancer gene therapy, Eur. J. Pharm. Sci., 52 (2014) 48-61.

[30] Y.K. Kim, A. Minai-Tehrani, J.H. Lee, C.S. Cho, M.H. Cho, H.L. Jiang, Therapeutic efficiency of folated poly(ethylene glycol)-chitosan-graft-polyethylenimine-Pdcd4 complexes in H-ras12V mice with liver cancer, Int. J. Nanomedicine, 8 (2013) 1489-1498.

[31] J.M. Li, Y.Y. Wang, W. Zhang, H. Su, L.N. Ji, Z.W. Mao, Low-weight polyethylenimine cross-linked 2-hydroxypopyl-beta-cyclodextrin and folic acid as an efficient and nontoxic siRNA carrier for gene silencing and tumor inhibition by VEGF siRNA, Int. J. Nanomedicine, 8 (2013) 2101-2117.

[32] J. Shi, H. Zhang, L. Wang, L. Li, H. Wang, Z. Wang, Z. Li, C. Chen, L. Hou, C. Zhang, Z. Zhang, PEI-derivatized fullerene drug delivery using folate as a homing device targeting to tumor, Biomaterials, 34 (2013) 251-261.

[33] M.E. Werner, J.A. Copp, S. Karve, N.D. Cummings, R. Sukumar, C. Li, M.E. Napier, R.C. Chen, A.D. Cox, A.Z. Wang, Folate-targeted polymeric nanoparticle formulation of docetaxel is an effective molecularly targeted radiosensitizer with efficacy dependent on the timing of radiotherapy, ACS Nano, 5 (2011) 8990-8998.

[34] L.Y. Qiu, L. Yan, L. Zhang, Y.M. Jin, Q.H. Zhao, Folate-modified poly(2-ethyl-2-oxazoline) as hydrophilic corona in polymeric micelles for enhanced intracellular doxorubicin delivery, Int. J. Pharm., 456 (2013) 315-324. 
[35] W. Wu, Y. Zheng, R. Wang, W. Huang, L. Liu, X. Hu, S. Liu, J. Yue, T. Tong, X. Jing, Antitumor activity of folate-targeted, paclitaxel-loaded polymeric micelles on a human esophageal EC9706 cancer cell line, Int. J. Nanomedicine, 7 (2012) 3487-3502.

[36] R. Wang, X. Hu, S. Wu, H. Xiao, H. Cai, Z. Xie, Y. Huang, X. Jing, Biological characterization of folate-decorated biodegradable polymer-platinum(II) complex micelles, Mol. Pharm., 9 (2012) 3200-3208.

[37] H.P. Chen, F.I. Tung, M.H. Chen, T.Y. Liu, A magnetic vehicle realized tumor cell-targeted radiotherapy using low-dose radiation, J. Control. Release, 226 (2016) 182-192.

[38] L. Dai, Y. Yu, Z. Luo, M. Li, W. Chen, X. Shen, F. Chen, Q. Sun, Q. Zhang, H. Gu, K. Cai, Photosensitizer enhanced disassembly of amphiphilic micelle for ROS-response targeted tumor therapy in vivo, Biomaterials, 104 (2016) 1-17.

[39] R.K. Thapa, J.Y. Choi, B. Gupta, T. Ramasamy, B.K. Poudel, S.K. Ku, Y.S. Youn, H.G. Choi, C.S. Yong, J.O. Kim, Liquid crystalline nanoparticles encapsulating cisplatin and docetaxel combination for targeted therapy of breast cancer, Biomater Sci, 4 (2016) 1340-1350.

[40] G. Hu, X. Cun, S. Ruan, K. Shi, Y. Wang, Q. Kuang, C. Hu, W. Xiao, Q. He, H. Gao, Utilizing G2/M retention effect to enhance tumor accumulation of active targeting nanoparticles, Sci Rep, 6 (2016) 27669.

[41] H. Yi, P. Liu, N. Sheng, P. Gong, Y. Ma, L. Cai, In situ crosslinked smart polypeptide nanoparticles for multistage responsive tumor-targeted drug delivery, Nanoscale, 8 (2016) 5985-5995.

[42] K.D. Lee, S.H. Choi, H. Kim da, H.Y. Lee, K.C. Choi, Self-organized nanoparticles based on chitosan-folic acid and dextran succinate-doxorubicin conjugates for drug targeting, Arch. Pharm. Res., 37 (2014) 1546-1553.

[43] M. Wang, H. Hu, Y. Sun, L. Qiu, J. Zhang, G. Guan, X. Zhao, M. Qiao, L. Cheng, L. Cheng, D. Chen, A pH-sensitive gene delivery system based on folic acid-PEG-chitosan PAMAM-plasmid DNA complexes for cancer cell targeting, Biomaterials, 34 (2013) 10120-10132.

[44] J.S. Kim, M.H. Oh, J.Y. Park, T.G. Park, Y.S. Nam, Protein-resistant, reductively dissociable polyplexes for in vivo systemic delivery and tumor-targeting of siRNA, Biomaterials, 34 (2013) 2370-2379.

[45] C. Yang, D. Li, Q. Fengzhao, L. Wang, L. Wang, Z. Yang, Disulfide bond reduction-triggered molecular hydrogels of folic acid-Taxol conjugates, Org. Biomol. Chem., 11 
(2013) 6946-6951.

[46] X. Liang, Y. Sun, W. Zeng, L. Liu, X. Ma, Y. Zhao, J. Fan, Synthesis and biological evaluation of a folate-targeted rhaponticin conjugate, Bioorg. Med. Chem., 21 (2013) 178-185.

[47] R. Onodera, K. Motoyama, A. Okamatsu, T. Higashi, H. Arima, Potential use of folate-appended methyl-beta-cyclodextrin as an anticancer agent, Sci Rep, 3 (2013) 1104.

[48] Q. Zeng, H. Wen, Q. Wen, X. Chen, Y. Wang, W. Xuan, J. Liang, S. Wan, Cucumber mosaic virus as drug delivery vehicle for doxorubicin, Biomaterials, 34 (2013) 4632-4642.

[49] W. Shao, A. Paul, B. Zhao, C. Lee, L. Rodes, S. Prakash, Carbon nanotube lipid drug approach for targeted delivery of a chemotherapy drug in a human breast cancer xenograft animal model, Biomaterials, 34 (2013) 10109-10119.

[50] N.V. Nukolova, H.S. Oberoi, S.M. Cohen, A.V. Kabanov, T.K. Bronich, Folate-decorated nanogels for targeted therapy of ovarian cancer, Biomaterials, 32 (2011) 5417-5426.

[51] F. Gao, L. Li, T. Liu, N. Hao, H. Liu, L. Tan, H. Li, X. Huang, B. Peng, C. Yan, L. Yang, X. Wu, D. Chen, F. Tang, Doxorubicin loaded silica nanorattles actively seek tumors with improved anti-tumor effects, Nanoscale, 4 (2012) 3365-3372.

[52] L. Xu, J. Betker, H. Yin, T.J. Anchordoquy, Ligands located within a cholesterol domain enhance gene delivery to the target tissue, J. Control. Release, 160 (2012) 57-63.

[53] L. Xu, S. Kittrell, W.A. Yeudall, H. Yang, Folic acid-decorated polyamidoamine dendrimer mediates selective uptake and high expression of genes in head and neck cancer cells, Nanomedicine (Lond), 11 (2016) 2959-2973.

[54] P.S. Low, S.A. Kularatne, Folate-targeted therapeutic and imaging agents for cancer, Curr. Opin. Chem. Biol., 13 (2009) 256-262.

[55] P.S. Low, W.A. Henne, D.D. Doorneweerd, Discovery and development of folic-acid-based receptor targeting for imaging and therapy of cancer and inflammatory diseases, Acc. Chem. Res., 41 (2008) 120-129.

[56] J.A. Reddy, C. Abburi, H. Hofland, S.J. Howard, I. Vlahov, P. Wils, C.P. Leamon, Folate-targeted, cationic liposome-mediated gene transfer into disseminated peritoneal tumors, Gene Ther., 9 (2002) 1542-1550.

[57] D.A. Brill, J.A. MacKay, Image-driven pharmacokinetics: nanomedicine concentration across space and time, Nanomedicine (Lond), 10 (2015) 2861-2879. 
[58] M. Norouzi, B. Nazari, D.W. Miller, Injectable hydrogel-based drug delivery systems for local cancer therapy, Drug Discov. Today, (2016).

[59] R. Rosiere, M. Van Woensel, V. Mathieu, I. Langer, T. Mathivet, M. Vermeersch, K. Amighi, N. Wauthoz, Development and evaluation of well-tolerated and tumor-penetrating polymeric micelle-based dry powders for inhaled anti-cancer chemotherapy, Int. J. Pharm., 501 (2016) 148-159.

[60] D. Desai, N. Prabhakar, V. Mamaeva, D.S. Karaman, I.A. Lahdeniemi, C. Sahlgren, J.M. Rosenholm, D.M. Toivola, Targeted modulation of cell differentiation in distinct regions of the gastrointestinal tract via oral administration of differently PEG-PEI functionalized mesoporous silica nanoparticles, Int. J. Nanomedicine, 11 (2016) 299-313.

[61] J.L. Kovar, W.M. Volcheck, J. Chen, M.A. Simpson, Purification method directly influences effectiveness of an epidermal growth factor-coupled targeting agent for noninvasive tumor detection in mice, Anal. Biochem., 361 (2007) 47-54.

[62] J. Shi, B. Wang, Z. Chen, W. Liu, J. Pan, L. Hou, Z. Zhang, A Multi-Functional Tumor Theranostic Nanoplatform for MRI Guided Photothermal-Chemotherapy, Pharm. Res., 33 (2016) 1472-1485.

[63] J.M. Liu, J.T. Chen, X.P. Yan, Near infrared fluorescent trypsin stabilized gold nanoclusters as surface plasmon enhanced energy transfer biosensor and in vivo cancer imaging bioprobe, Anal. Chem., 85 (2013) 3238-3245.

[64] X. Wang, A.R. Morales, T. Urakami, L. Zhang, M.V. Bondar, M. Komatsu, K.D. Belfield, Folate receptor-targeted aggregation-enhanced near-IR emitting silica nanoprobe for one-photon in vivo and two-photon ex vivo fluorescence bioimaging, Bioconjug. Chem., 22 (2011) 1438-1450.

[65] I. Hajdu, M. Bodnar, G. Trencsenyi, T. Marian, G. Vamosi, J. Kollar, J. Borbely, Cancer cell targeting and imaging with biopolymer-based nanodevices, Int. J. Pharm., 441 (2013) 234-241.

[66] G.B. Hong, J.X. Zhou, R.X. Yuan, Folate-targeted polymeric micelles loaded with ultrasmall superparamagnetic iron oxide: combined small size and high MRI sensitivity, Int. J. Nanomedicine, 7 (2012) 2863-2872.

[67] J. Reber, H. Struthers, T. Betzel, A. Hohn, R. Schibli, C. Muller, Radioiodinated folic acid conjugates: evaluation of a valuable concept to improve tumor-to-background contrast, Mol. Pharm., 9 (2012) 1213-1221.

[68] H. Wang, L. Zheng, C. Peng, M. Shen, X. Shi, G. Zhang, Folic acid-modified 
dendrimer-entrapped gold nanoparticles as nanoprobes for targeted CT imaging of human lung adencarcinoma, Biomaterials, 34 (2013) 470-480.

[69] Q. Chen, K. Li, S. Wen, H. Liu, C. Peng, H. Cai, M. Shen, G. Zhang, X. Shi, Targeted CT/MR dual mode imaging of tumors using multifunctional dendrimer-entrapped gold nanoparticles, Biomaterials, 34 (2013) 5200-5209.

[70] C.M. Paulos, J.A. Reddy, C.P. Leamon, M.J. Turk, P.S. Low, Ligand binding and kinetics of folate receptor recycling in vivo: impact on receptor-mediated drug delivery, Mol. Pharmacol., 66 (2004) 1406-1414.

[71] C.P. Leamon, P.S. Low, Folate-mediated targeting: from diagnostics to drug and gene delivery, Drug Discov. Today, 6 (2001) 44-51.

[72] E. Blanco, H. Shen, M. Ferrari, Principles of nanoparticle design for overcoming biological barriers to drug delivery, Nat. Biotechnol., 33 (2015) 941-951.

[73] M. Longmire, P.L. Choyke, H. Kobayashi, Clearance properties of nano-sized particles and molecules as imaging agents: considerations and caveats, Nanomedicine (Lond), 3 (2008) 703-717.

[74] J. Holm, S.I. Hansen, M. Hoier-Madsen, L. Bostad, A high-affinity folate binding protein in proximal tubule cells of human kidney, Kidney Int., 41 (1992) 50-55.

[75] J. Selhub, W.A. Franklin, The folate-binding protein of rat kidney. Purification, properties, and cellular distribution, J. Biol. Chem., 259 (1984) 6601-6606.

[76] J. Selhub, D. Emmanouel, T. Stavropoulos, R. Arnold, Renal folate absorption and the kidney folate binding protein. I. Urinary clearance studies, Am. J. Physiol., 252 (1987) F750-756.

[77] J. Selhub, S. Nakamura, F.A. Carone, Renal folate absorption and the kidney folate binding protein. II. Microinfusion studies, Am. J. Physiol., 252 (1987) F757-760.

[78] W.M. Williams, K.C. Huang, Renal tubular transport of folic acid and methotrexate in the monkey, Am. J. Physiol., 242 (1982) F484-490.

[79] S.H. Lee, J.B. Lee, M.S. Bae, D.A. Balikov, A. Hwang, T.C. Boire, I.K. Kwon, H.J. Sung, J.W. Yang, Current progress in nanotechnology applications for diagnosis and treatment of kidney diseases, Adv Healthc Mater, 4 (2015) 2037-2045.

[80] J.A. Jefferson, S.J. Shankland, R.H. Pichler, Proteinuria in diabetic kidney disease: a 
mechanistic viewpoint, Kidney Int., 74 (2008) 22-36.

[81] J. Wartiovaara, L.G. Ofverstedt, J. Khoshnoodi, J. Zhang, E. Makela, S. Sandin, V. Ruotsalainen, R.H. Cheng, H. Jalanko, U. Skoglund, K. Tryggvason, Nephrin strands contribute to a porous slit diaphragm scaffold as revealed by electron tomography, J. Clin. Invest., 114 (2004) 1475-1483.

[82] S.F. Knight, K. Kundu, G. Joseph, S. Dikalov, D. Weiss, N. Murthy, W.R. Taylor, Folate receptor-targeted antioxidant therapy ameliorates renal ischemia-reperfusion injury, J. Am. Soc. Nephrol., 23 (2012) 793-800.

[83] P.E. Kintzel, R.T. Dorr, Anticancer drug renal toxicity and elimination: dosing guidelines for altered renal function, Cancer Treat. Rev., 21 (1995) 33-64.

[84] R. Skinner, Strategies to prevent nephrotoxicity of anticancer drugs, Curr. Opin. Oncol., 7 (1995) 310-315.

[85] I. Arany, J.K. Megyesi, H. Kaneto, P.M. Price, R.L. Safirstein, Cisplatin-induced cell death is EGFR/src/ERK signaling dependent in mouse proximal tubule cells, Am. J. Physiol. Renal Physiol., 287 (2004) F543-549.

[86] I. Arany, R.L. Safirstein, Cisplatin nephrotoxicity, Semin. Nephrol., 23 (2003) 460-464.

[87] R. Torres, H. Velazquez, J.J. Chang, M.J. Levene, G. Moeckel, G.V. Desir, R. Safirstein, Three-Dimensional Morphology by Multiphoton Microscopy with Clearing in a Model of Cisplatin-Induced CKD, J. Am. Soc. Nephrol., 27 (2016) 1102-1112.

[88] A.B. Kramer, M.M. van Timmeren, T.A. Schuurs, V.S. Vaidya, J.V. Bonventre, H. van Goor, G. Navis, Reduction of proteinuria in adriamycin-induced nephropathy is associated with reduction of renal kidney injury molecule (Kim-1) over time, Am. J. Physiol. Renal Physiol., 296 (2009) F1136-1145.

[89] V.W. Lee, D.C. Harris, Adriamycin nephropathy: a model of focal segmental glomerulosclerosis, Nephrology (Carlton), 16 (2011) 30-38.

[90] K. Yasuda, H.C. Park, B. Ratliff, F. Addabbo, A.K. Hatzopoulos, P. Chander, M.S. Goligorsky, Adriamycin nephropathy: a failure of endothelial progenitor cell-induced repair, Am. J. Pathol., 176 (2010) 1685-1695. 


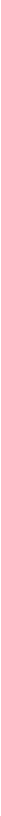

